\title{
The Importance of Boosting Students' Intercultural Competence in Moroccan EFL Classes
}

\author{
ENAIM RACHID \\ Ibn Tofail University: faculty of Languages, Humanities, and Arts, Kenitra, Morocco
}

\begin{abstract}
Because intercultural communicative competence has a tremendous influence on the cultural component of language teaching/ learning, this article is a concise literature review of intercultural competence. In fact, curricula designers have put a strong emphasis on the definitions and implementations of intercultural communication to provide tasks that enhance learners' cross-cultural competences. It is worth mentioning that intercultural competence is not a new concept in the field of language teaching and learning, but it is renewed by certain studies and surveys. People nowadays must be interculturally competent to able to deal with the $21^{\text {st }}$ century challenges that lead to a lot of cultural misunderstandings. However, one may suggest that learners can interact communicatively despite the language skills they may lack. As such, this article is seeking to answer questions such as how can Moroccan EFL classes boost learners' intercultural competences?
\end{abstract}

Keywords: Intercultural Communication, Intercultural Competence, Intercultural Communicative Competence

DOI: $10.7176 / \mathrm{JEP} / 12-22-02$

Publication date:August $31^{\text {st }} 2021$

\section{I.Introduction}

Intercultural communication is inescapable, for it takes place on a daily basis. People are in a constant state of interactions among each other. Being able to interact successfully in cross-cultural contexts calls for acquiring and learning the intercultural competences needed. People must acquire cross cultural knowledge because of living in this globalized world. "Developments in transportation and communication technology have been rapidly removing geographical boundaries" (Lee, 2003, p. 3). For example, when two people who belong to different cultures interact, a third culture pops up because people move across cultural boundaries. A grey space, or common ground, where the two interactants negotiate meanings is needed to get rid of potential misunderstandings that are conducive to conflicts. Most of us, when coming across the term intercultural communication, think it is about knowing other cultures. This is a traditional view of the issue, as modern analyses and studies of intercultural competence "emphasize the importance of analysing your self and your consciousness and to know yourself first, in order that you would know what is valuable to other cultures"( Patel et al., 2011, p. 26). The world is full of cultural stereotypes and misunderstandings which can be ascribed to lack of intercultural knowledge dominating relations among peoples from different parts of the world. Citizens of the world judge each other by having a look at the surface structure of cultures such as clothes and food manners due to people's inability to see the deeply-held beliefs of each society. Cultures have both a surface level, which everyone sees, and a deep structure, which governs social manners and behaviors. That is why some theoreticians, such as Edward T. Hall (1976), strongly believe the Iceberg theory of culture can be of great use to show that cultures have a side plainly observed and a hidden one governing behaviors.

Accordingly, intercultural competence is becoming necessary nowadays if people are able to communicate with each other in successful ways. Therefore, endeavors have been tried to enhance people's cross-cultural knowledge through media, cultural exchange programs, and, more importantly, language teaching/ learning. The latter is extremely important because students must possess several intercultural skills so that they can deal with the Other. EFL classes are good examples and platforms to boost cross-cultural knowledge through enhancing cultures. Moroccan EFL classes, high school ones in particular, teach in implicit manners cultures or at least introduce cultural issues related to local and foreign cultures. Language teaching and learning can be highly effective when teachers and curricula designers link language skills with cross-cultural communicative competence so that learners become able to operate globally (Moeller \&Nugent, 2014). One of the basic questions this article tries to answer is that is it possible to be cross-culturally competent through language teaching and learning?

\section{What is Intercultural Competence?}

Intercultural competence, also known as cross-cultural competence, has always been at the center of many debates around the theme of communicating with people belonging to different cultures either in real-life situations or in virtual cases. Many intellectuals worthy of the name have talked about intercultural competence in its wider and specific senses, each according to their beliefs and backgrounds. Therefore, there are many definitions of intercultural competence according to experts' fields of interests. To come up with a concise definition of intercultural competence is not an easy task. Cross-cultural competence can be defined as a: 
"combination of attitudes, knowledge, understanding and skills applied through action which enables one, either singly or together with others, to:

- understand and respect people who are perceived to have different cultural affiliations from oneself;

- respond appropriately, effectively and respectfully when interacting and communicating with such people;

- establish positive and constructive relationships with such people”. (Barrett et al., 2014, p. 17)

Intercultural competence revolves around the theme of being able to communicate with someone who belongs to a different cultural mindset. An important feature of intercultural communication has been that it is a process full of personal interpretations of messages. When a cross-cultural exchange takes place, interactants' cultural parameters intervene to decode messages. If a person is not interculturally competent enough, they are likely to misunderstand the speaker/ sender. This emphasis on a "person's perception of the world around $\mathrm{him} / \mathrm{her}$ is deeply entrenched in the system of symbols that his or her culture uses to make sense of the world" (Patel et al, p. 40). Another important definition of intercultural competence is the one provided by Samovar and Porter. They think cross-cultural communication is "interaction between people whose cultural perceptions and symbol systems are distinct enough to alter the communication event" (Samovar, 2004, p. 15). When people are not familiar with the belief systems and values on which a cultural gesture is based, misinterpretations often take place. Misunderstandings are likely to happen due to lack of cultural dissimilarities existing among cultures.

\section{III.The Importance of Developing Learners' Intercultural Competence}

With the movements of people and the advent of Information and Communication Technologies, there is an urgent need for the cultural component in foreign language teaching/ learning. Associating culture with language learning has attracted the attention of many scholars. Moeller and Nugent (2014) argue "the linking of language and culture in the foreign language classroom has been the focus of much scholarly inquiry (Kramsch, 1993; Byram, 1989; Liddicoat, 2002, Liddicoat \& Scarino, 2013)" (p. 2). It would be completely right to assume that culture and language are interrelated, and are closely interdependent. Learners should be aware of the fact that different countries have a variety of ways of living and thinking. Students' need to be interculturally competent is ascribed to two main reasons. From a microscopic perspective, a good mastery of language cannot be attained without taking into account the culture of that language, while, at the macroscopic level, learners are citizens of the world; hence, they need the necessary tools to operate in this globalized world. As learners engage in analyzing other cultures, a given level of intercultural competence is gained. The ultimate purposes behind enhancing intercultural competence can be summarized in five main areas:

1. Valuing difference and diversity

2. Acquiring cultural acceptance

3. Being aware of cultural differences

4. Being able to deal with twenty-first-century challenges

5. Being a citizen of the world

However, teachers face a big challenge to assess whether students have learnt the necessary skills and knowledge to be interculturally competent because most of methods of assessment are meant for language issues like grammar, spelling, and so on. It is not easy to measure to what extent learners get the desired outcomes; it is even impossible to obtain measureable consequences.

\section{IV.The Cultural Component of Moroccan EFL Classes}

The teaching of English in Morocco is based on preparing learners to be autonomous and be able to deal with real-life situations. Morocco adopts the standards-based approach which aims at, apart from language mastery, "comparing and contrasting our languages and culture(s) with other languages and culture(s) leads to better understanding of ours" (pedagogical official guidelines, 2007, p. 6). The standards-based approach is built upon 5 main Cs, namely Communication, Connections, Comparisons, Communities, and Cultures. The purpose behind including culture in teaching English as a foreign language in Morocco is to help learners "gain deeper understanding of their culture(s) and other cultures in terms of their perspectives (e.g. values, ideas, attitudes, etc.), practices (pattern of social interactions), and products (e.g. books, laws, music, etc)....gain awareness of cross-cultural similarities and differences (in terms of both language(s) and culture" (Ibid, p. 6). The enhancement of intercultural awareness through language teaching is not an easy task. Byram (1997) believes teachers have an important role to play in cross-cultural environment classrooms because they should guide learners and give them more opportunities to have exposure to foreign language documents which include cultural elements of the target languages.

The teaching of the four skills - reading, writing, grammar, and speaking- aims at helping learners acquire certain competencies that suit both the linguistic and cultural components of language learning. As already stated, 
learners should be able to use the target language appropriately. Achieving this objective calls for helping learners acquire certain competencies such as grammatical, discursive, socio-cultural, and strategic competence. This article focuses on the last two competencies because they include a cultural component. Socio-cultural competence is about "the ability to understand and use utterances appropriately in different sociolinguistic contexts depending on contextual factors/ clues", while strategic competence refers to "the ability to make use of verbal and non-verbal communication strategies (a) to make up for breakdowns in communication and (b) to boost the effectiveness of communication"(Ibid, p. 10). When learners are asked to do a role-play, they are exposed to the target culture for it is a part of the language they learn. Another evidence of the presence of culture in Moroccan EFL classes is embedded in reading comprehension texts. According to the official pedagogical guidelines (2007), reading "provides learners with the opportunity to know and interact with other cultures and experiences"(Ibid, p. 22). If learners do not acquire intercultural communicative competence, they may fall in the trap of misunderstandings and tensions whenever they engage in cross-cultural exchanges. That is why teachers of English in Morocco should do their very best to develop learners' intercultural competences. The adoption of the official pedagogical guidelines for the teaching of English in Morocco helps teachers to prepare learners to meet global societal needs to be part of the world. Teachers of foreign languages should be interculturally competent. Davitishvili states that:

"Becoming a teacher in an internationalized world and in a multicultural society requires intercultural competence. Personal as well as professional development is called for to enhance the teacher's intercultural understanding. The aim of this course is to create possibilities for the student to develop knowledge, skills and attitudes to meet these new demands through theoretical and practical tools as well as through experiential learning". (2017, p. 132-133)

\section{Some Tips to Boost EFL Students'Intercultural Communicative Competence}

Teachers all over the world should reconsider the methods and techniques to help learners be cross-culturally competent language-users because traditional methods focus on the linguistic component. A learner is believed to be good when he/she displays good language mastery in terms of pronunciation, terminology, grammar, and so on. An interculturally competent person is someone who is able to turn intercultural misunderstandings into effective cross-cultural relations through enhancing the others' views of local cultures (Byram, 1997). These are some of the activities which enhance learners' intercultural communicative competence:

\subsection{Online-based discussions}

The Internet has open horizons for language learning and teaching for it helps both teachers and students create conversations with students from foreign cultures, be they native speakers or learners from other countries. Teachers can create a platform that might be called "Bring Cultures to Classrooms". This platform helps students and their teacher launch videoconferences with English native speakers, from USA, England, Wales, among others, and engage in online discussions. Students, participants, are asked to analyze some photos that entail a cultural touch from both the local and foreign culture. This kind of activities has led to cultural discovery because learners discuss the differences and similarities among the cultures engaged. What makes this experience successful is that students become more aware of their cultural structures, and gain knowledge about the cultures they are exposed to. Whenever there is an event that includes a cultural touch, we invite others to join us for discussion, and vice-versa. We also discuss a number of proverbs and idioms because they are pregnant with cultural backgrounds. In the end, most students, engaged in this program, become cross-culturally competent due to knowing others' worldview, and, finally, they can get rid of the stereotypes held against the other.

\subsection{English clubs}

Students and teachers of English establish English clubs to promote language learning. Thanks to these clubs, teachers can invite some guests from other countries. This provides students with opportunities for real exposure to the target language, and, hence, culture. Schools can invite some American teachers who work in teen-centers in the city to talk about their experiences about the culture shocks they have come across. Students try to help the speakers by suggesting some solutions to these issues. They question the guest about their cultures. They, as a result, become aware of some differences and similarities between the two cultures.

\section{VI.Conclusion}

Language proficiency has always been at the core of language teaching/learning, but it is no longer the dominant feature. The standards-based approach, as stated in the official guidelines (2007) in Morocco, defines the purposes of language teaching and learning in relation to the 5Cs: Communication, Cultures, Connections, Communities, and Comparisons. "An interculturally competent speaker of a foreign language possesses both communicative competence in that language as well as particular skills, attitudes, values and knowledge about a 
culture" (Moeller and Nugent, 2014, p. 3). When learners are exposed to foreign cultures, they are likely to better understand and come up with explanations of conflicts and misinterpretations. Students nowadays have great opportunities to encounter individuals from a variety of cultures. Intercultural competence is gaining more significance in language teaching and learning, for students from all parts of the world interacts with each other in a frequent manner. EFL teachers want their students to be able to see the hidden parts of cultures for avoiding misunderstandings that might pop up during cross-cultural exchanges.

\section{References}

Barrett, M., Ildiko, L., Byram, M., Mompoint-Gaillard, P., \& Stavroula , P. (2014). Developing Intercultural Competence through Education (Pestalozzi Series No. 3). Council of Europe.

Byram, M. (1997). Teaching and Assessing Intercultural Communicative Competence. Clevedon, UK: Multilingual Matters.

Central Specialist Coordination of English. (2007). English Language Guidelines for Secondary Schools: Common Core, First Year, and Second Year Baccalaureate. Rabat, Morocco.

Davitishvili, N. (2017). Cross-Cultural Awareness and Teaching English as a Second Language in the Context of Globalization. Sino-US English Teaching, 14(9), 549-558. doi: 10.17265/1539-8072/2017.09.003.

Finkbeiner, C. (2009). Using 'Human Global Positioning System' as a Navigation Tool to the Hidden Dimension of Culture. Becoming Interculturally Competent through Education and Training, 151-173. doi: 10.21832/9781847691644-012

Klyukanov, I. (2005). Principles of Intercultural Communication. S.1.: Routledge.

Lee, Suman. (2003). Beyond Cultural Boundary: An Empirical Study of the Third Culture Theory.' Retrieved from http://www. allacademic.com/meta/p112182 index.html.

Lundgren, U. (2009). 7. Intercultural Teacher: A Case Study of a Course. Becoming Interculturally Competent through Education and Training, 132-150. doi: 10.21832/9781847691644-011.

Moeller, A. K., \& Nugent, K. (2014). Building Intercultural Competence in the Language Classroom. University of Nebraska - Lincoln Publications: Department of Teaching, Learning and Teacher Education, 1-19. Retrieved from,https://digitalcommons.unl.edu/teachlearnfacpub/161/?utm_source=digitalcommons.unl.edu/teachlearn facpub/161\&utm_medium=PDF\&utm_campaign=PDFCoverPages.

Patel, Fay, Mingsheng, L., \& Prahalad, S. (2011). Intercultural Communication: Building a Global Community. London, UK: Sage Publications Inc.

Samovar, L. A., \& Porter, R. E. (2004). Communication between Cultures. Belmont (Calif.): Wadsworth/Thomson Learning.

Zhang, X. (2010). Developing Students' Intercultural Communication Competences in Western Etiquette Teaching. English Language Teaching, 3(4). doi: 10.5539/elt.v3n4p224. 